\title{
The Development of Teaching Comics to Improve Interest in Reading Civic Education in MIN Ramba Padang, South Tapanuli Regency, Indonesia
}

\author{
Maulana Arafat Lubis \\ IAIN Padangsidempuan, Indonesia \\ Email:maulanaarafat62@gmail.com
}

\begin{abstract}
Indonesians seek information from social media more than books. Development of PPKn teaching materials in increasing reading interest MIN Ramba Padang in South Tapanuli district will focus on PPKn material such as joint decisions. The development of this teaching material is in the form of comics. The purpose of this study was to develop comic teaching materials to increase students' reading interest in PPKn subjects at MIN Ramba Padangkab Selatan Tapanuli Regency. This research method is research and development ( $R$ \& D) method. This model is used to develop comics as teaching materials in high school SD / MI classes. While the subjects in this study were class V MIN Ramba Padang students who were located in Sipagimbar village, South Tapanuli regency as many as 17 people. The results of the study use the research method with ADDIE model.
\end{abstract}

Keywords: Development; PPKn teaching material; Comics

\section{Introduction}

Reading interest in Indonesia is very low, even compared to other countries such as Singapore and Malaysia. In reality, Indonesians seek information from social media more than books. For us, the book is an old-fashioned tool caused by being tempted by Android technology that is easier to carry around. World bank report no. 16369-IND (Education in Indonesia from Crisis to Recovery) states that the reading rate of the sixth grade of elementary schools in Indonesia is only able to score 51.7 below the Philippines (52.6), Thailand (65.1) and Singapore $(74,0)$.Somadayo stated that every aspect of life involved reading activities. In fact, interest in reading society, especially children as students, is still low.This is a challenge for teachers in elementary school education.

The low reading interest is caused by several things including the high price of books and the limited library facilities that cause reading is no longer a means of learning and entertainment for the people of Indonesia. Indonesian people prefer to buy television rather than buy books. To overcome this, teachers are required to be able to make innovations in the learning process. It aims to create an active, innovative, creative, effective and fun learning process. One effort to create this atmosphere, the teacher is able to make teaching materials that can make students interested in reading. One of the teaching materials is comics.

Educational deterioration is not caused by the curriculum, but by the lack of teacher professionalism and lack of student motivation. Professionalism emphasizes the mastery of 
science, classroom management, and learning theory. Professionalism is not just material knowledge, but is able to master technology, child psychology, and have the skills in making teaching materials. Professional teachers are basically determined by hard skills and soft skills.

Based on the results of the analysis of the interim researcher at MIN Ramba Padang, Sipagimbar village, South Tapanuli regency, in teaching in the classroom the teacher relied more on textbooks. Frequently teaching materials that are textbook center (centered on textbooks) make students feel bored in learning. In addition, the learning resources are very lacking for every student, this is due to teachers who are less creative in finding and making teaching materials. This finding is an impact of problems that will later become a factor students are no longer interested in reading. Until now the school is in desperate need of learning resources that contain teaching materials related to subject matter, even though the source of learning is one of the tools that must be owned by every school. This factor that makes students have no interest in reading is due to the lack of textbooks in the MIN Ramba Padang school. The learning resources that are not enough to make students interested in reading are caused by books that have been torn or used for years so that the book is not interesting to read. This is supported by the acquisition of interest in reading PPKn MIN Ramba Padang students as follows:

Tabel 1.The Results of Student PPKn Reading Interest MIN Ramba Padang Academic Year2017/2018

\begin{tabular}{|c|c|c|c|c|}
\hline No. & Class & Academic Year & Semester & $\begin{array}{c}\text { Percentage of Student Interest in } \\
\text { Reading PPKn }\end{array}$ \\
\hline 1 & 5 & $2017 / 2018$ & Ganjil & $30 \%$ \\
\cline { 4 - 5 } & \multirow{2}{*}{5} & Genap & $32 \%$ \\
\hline
\end{tabular}

(Source: Administration of MIN Ramba Padang, South Tapanuli Regency)

Based on the table above, it can be concluded that there are still low data on students' interest with a percentage of $30 \%$ in the odd semester and $32 \%$ in the middle of the even semester. This reality is a rebuke for teachers to fix problems that occur in order to increase student interest in reading MIN Ramba Padang Sipagimbar village, South Tapanuli district.

In connection with these problems need to be addressed by the teacher in learning who must have creativity in making teaching materials. Teachers do not have to expect books from the government, but are able to innovate in designing teaching materials that make students understand the lesson. The material to be taught is not just textbooks, newspapers, magazines. But comics can also be used as material for teaching, because comics can stimulate students due to the funny color combinations and stories. In addition, comics can also change the character of children later, due to the characters in comics that can make children enter the story in the comic.

Development of PPKn teaching materials in increasing reading interest MIN Ramba Padang in South Tapanuli district will focus on PPKn material such as joint decisions. The importance of joint decision material that students must apply in their daily lives. Therefore the development of this teaching material should be developed, in order to apply the attitude of decision with students. The development of this teaching material is in the form of comics. 
Therefore, the development of comic-shaped teaching materials is believed to increase students' reading interest.

\subsection{Formulation of Problem}

Based on the background stated, the problem of developing comic teaching materials can be formulated to increase the reading interest of MIN Ramba Padang students as follows:

1. How is the design of comic teaching materials developed in PPKn subjects used by MIN Ramba Padang students in South Tapanuli district?

2. How is the validity and effectiveness of teaching materials developed at MIN Ramba Padang, South Tapanuli district?

3. How to increase the results of reading interest of students of MIN Ramba Padang in South Tapanuli district by using comic book materials for PPKn subjects?

4.

\subsection{Objective of The Research}

In general, the purpose of this study was to develop comic teaching materials to increase students' reading interest in PPKn subjects at MIN Ramba Padangkab Selatan Tapanuli Regency. While specifically this research aims to:

1. Producing the design of comic teaching materials in the PPKn subjects used by MIN Ramba Padangkab Selatan Tapanuli district students.

2. Analyzing the validity and effectiveness of teaching materials developed at MIN Ramba Padang, South Tapanuli district.

3. Knowing the increasing reading interest of MIN Ramba Padang students in South 4. Tapanuli district by using comic teaching materials in PPKn subjects.

\subsection{Limitation of Term}

The limittation of term in this study are as follows:

1. Comic Teaching Materialsis material in the form of illustrated stories.

2. Student Reading Interestis the result of students' observation of comic teaching materials to increase reading interest of MIN Ramba Padang students in South Tapanuli district focusing on class 5 .

\subsection{Variables and Definition of Operational Variables}

The variables involved in this research can be explained as follows:

a. PPKn reading interestis an assessment conducted by teachers and researchers. Determination of increasing interest in reading PPKn students. The student's reading interest in question includes listening or paying attention to students directly.

b. Comic teaching materialsThe determination of the validity of the quality of comic teaching materials is based on an assessment determined by a team of experts consisting of three experts, namely: (1) Expert material on Pancasila and Citizenship Education named Dr. Reh Bungana Br. Perangin-angin, M.Hum, (2) Linguists named Tasnim Lubis, M.Hum, and (3) Experts draw illustrations named Adek Cerah Kurnia Azis, M.Pd to find out the effectiveness of comic teaching materials, then data collection using sheets observation. Assessment observation sheet contains indicators of quality of comic. 
c. Teacher and student responsesused to determine the quality of comic teaching materials in increasing students' reading interest through questionnaires.

\section{Method of The Research}

This research method is research and development (R \& D) method. This model is used to develop comics as teaching materials in high school SD / MI classes. While the subjects in this study were class V MIN Ramba Padang students who were located in Sipagimbar village, South Tapanuli regency as many as 17 people. The object in this study is the development of comic teaching materials and increasing students' interest in reading PPKn. The trial was conducted at MIN Ramba Padang in Sipagimbar village, South Tapanuli regency with the following considerations:

a. Openness of school principals and teacher councils to accept innovation in the constructive teaching and learning process.

b. The low reading interest of students in learning PPKn by using teaching materials used so far.

While the object of this research is the development of comic teaching materials.

This study uses the ADDIE research and development model. Here are the ADDIE stages in the picture below.

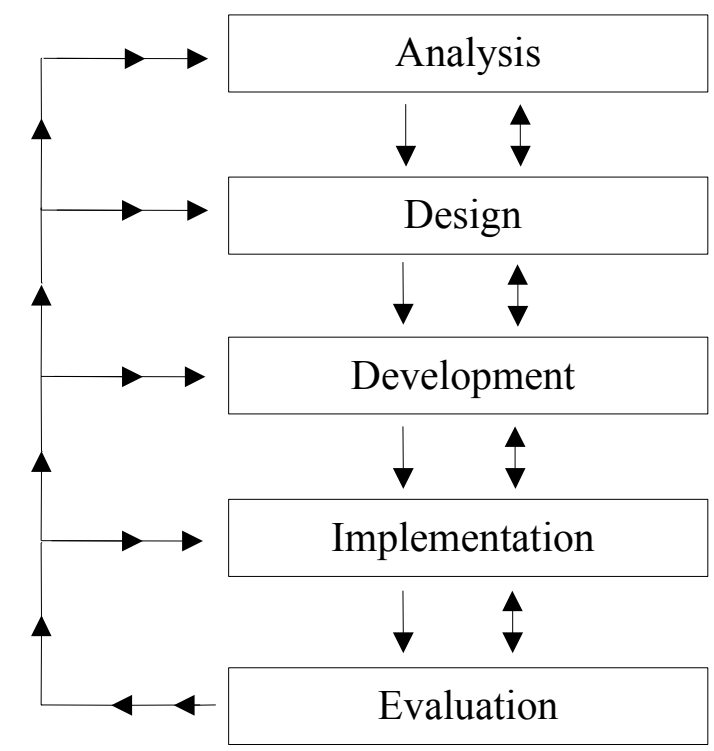

Pigure 1. Picture of ADDIE Research and Development Model 


\section{Result of The Research}

The following results of the study use the research method with ADDIE model:

\subsection{Stages of the Analysis (Analysis)}

Based on the results of the preliminary analysis at MIN Ramba Padang, Sipagimbar Village, South Tapanuli district, in class learning, teachers relied more on textbooks. Even there are still many students who do not get a package book, so students only have one book on one table consisting of two students. In addition, teaching materials that are textbook center (centered on textbooks) make students feel bored in learning. In addition, the learning resources are very lacking for every student, this is due to teachers who are less creative in finding and making teaching materials. The data obtained by the percentage of students' interest in reading PPKn in the 2017/2018 academic year in the odd semester is $30 \%$ and the mid semester is even $32 \%$.

\subsection{Stages of the Design (Design)}

So the comic teaching material developed in this study has the following elements: (1) cover; (2) competency standards, basic competencies, indicators and learning objectives; (3) character recognition; (4) comic material is elaborated through pictures and dialogues that clearly express facial, background, lines of motion, and word balloons; (5) the author's profile; and (6) the synopsis of comics.

Table 2. Framework for Preparing Comic Teaching Material Design

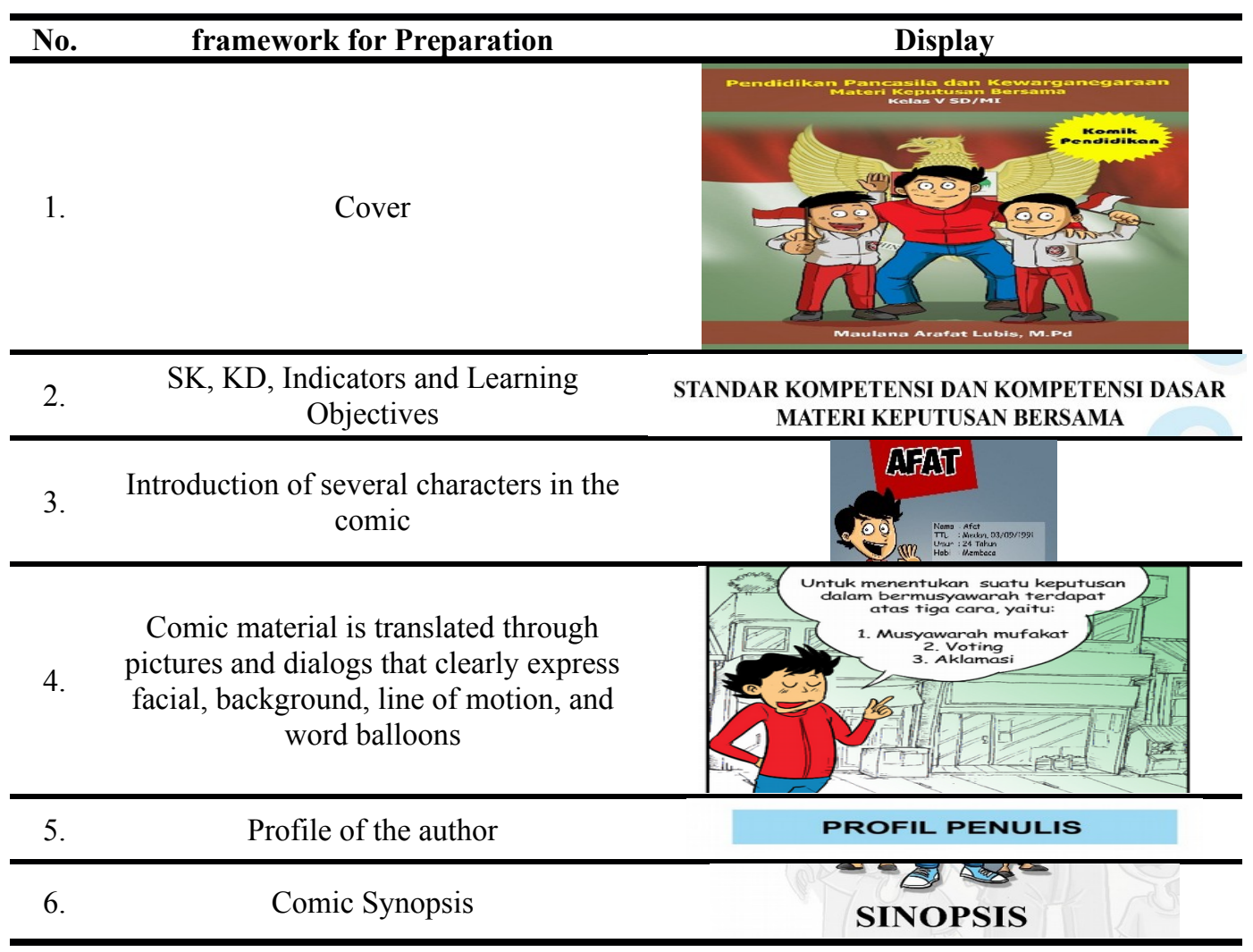


Table 3. PPKn Material Preparation Framework

\begin{tabular}{cccc}
\hline $\begin{array}{c}\text { Learning } \\
\text { activities }\end{array}$ & \multicolumn{1}{c}{ Indicator } & Material Description \\
\hline $\mathbf{1 .}$ & $\circ$ & Knowing the forms of joint decisions & $\circ$ Joint Decision \\
\hline $\mathbf{2 .}$ & $\circ$ & Analyzing the principles of joint decisions in consensus & $\circ$ Joint Decision \\
& $\circ$ & Applying the procedures for joint decision making in \\
& & consensus deliberations by means of voting and acclamation & \\
\end{tabular}

\subsection{Stages of the Development (Development)}

Table 4. Preparation of Comic Teaching Materials as Initial Products

No. framework for Preparation
Cover
2.
SK, KD, Indicators and
Learning Objectives
I.
Introduction of several
characters in the comic




No. framework for Preparation
Comic material is translated
through pictures and dialogs
that clearly express facial,
background, line of motion, and

5. Profile of the author

Table 5. Results of Expert Validation on Comic Teaching Materials

\begin{tabular}{ccccc}
\hline No. & Expert Validator & Percentage & Validity & Appropriateness \\
\hline 1 & Material & $91,67 \%$ & Very Valid & Very Appropriate \\
\hline 2 & Language & $95,00 \%$ & Very Valid & Very Appropriate \\
\hline 3 & Picture Illustration & $100,00 \%$ & Very Valid & Very Appropriate \\
\hline & Rata-rata & $95,56 \%$ & Very Valid & Very Appropriate \\
\hline
\end{tabular}

Percentage of Score\%

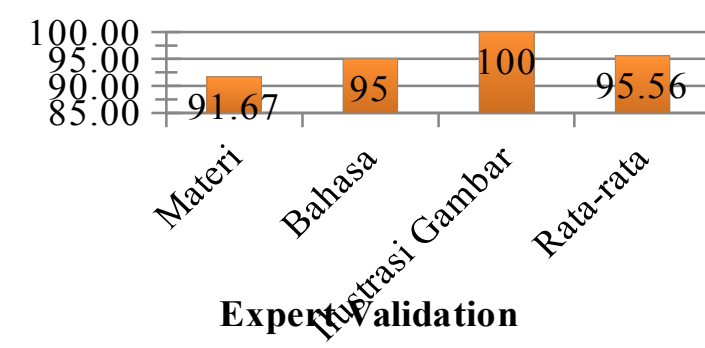

Figure 2. Picture of Expert Validation Results on Comic Teaching Materials 


\subsection{Stages of Implementation (Implementation)}

\section{1) PPKn Reading Interest in Trials Based on Questionnaire}

PPKn reading interest in grade $\mathrm{V}$ students when using Comic Teaching Materials in trial I and in trial II based on questionnaires is presented in the Table below.

Table 6. PPKn Interest Reading Table in Trial Based on the Questionnaire

\begin{tabular}{cccccc}
\hline & Trials I & \multicolumn{3}{c|}{ TrialsII } \\
\hline Score & F & f relative (\%) & Score & F & f relative (\%) \\
\hline $61-70$ & 11 & 64,71 & $61-70$ & 0 & 0,00 \\
\hline $71-80$ & 6 & 35,29 & $71-80$ & 1 & 5,88 \\
\hline $81-90$ & 0 & 0,00 & $81-90$ & 4 & 23,53 \\
\hline $91-100$ & 0 & 0,00 & $91-100$ & 12 & 70,59 \\
\hline Total & $\mathbf{1 7}$ & $\mathbf{1 0 0}$ & Total & $\mathbf{1 7}$ & $\mathbf{1 0 0}$ \\
\hline Mean & $\mathbf{6 9 , 7 1}$ & & Mean & $\mathbf{9 2 , 9 4}$ & \\
\hline Stdev & $\mathbf{4 , 2 3}$ & & Stdev & $\mathbf{5 , 1 7}$ & \\
\hline
\end{tabular}

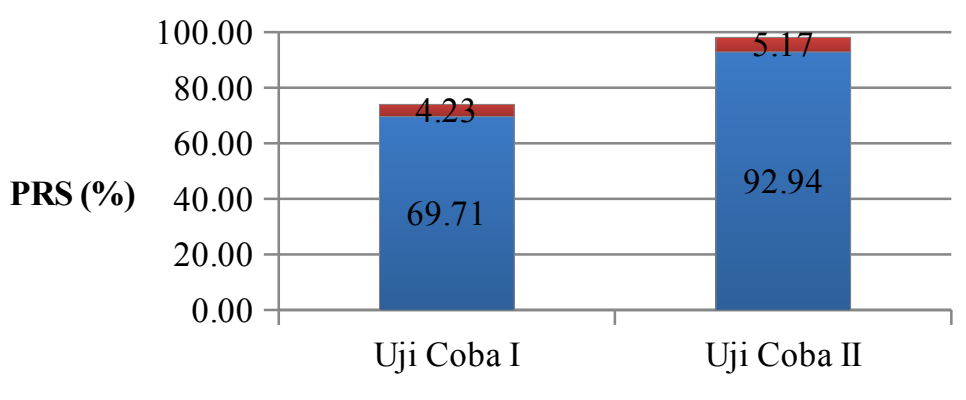

Questionnaire Student Reading Interest

Figure 3. Image of Student Reading Interest Based on Questionnaire

The table above shows that class $\mathrm{V}$ students obtained questionnaire values for the average PPKn reading interest, which was 69.71 in the first trial and 92.94 in the second trial. This shows that there is a difference even an increase in the score of PPKn reading interest questionnaire from the first product trial to the second product trial.

\section{2) PPKn Reading Interest in Trials Based on Observations}

PPKn reading interest in grade V students when using Comic Teaching Materials in trial I and in trial II based on Observations are presented in the Table below.

Table 7. PPKn Reading Interests in Trials Based on Observations

\begin{tabular}{cccccc}
\hline & Uji Coba I & \multicolumn{3}{c|}{ Uji Coba II } \\
\hline Score & F & f relative (\%) & Score & F & f relative (\%) \\
\hline $51-60$ & 5 & 29,41 & $61-70$ & 0 & 0,00 \\
\hline $61-70$ & 4 & 23,53 & $61-70$ & 0 & 0,00 \\
\hline
\end{tabular}




\begin{tabular}{cccccc}
\hline $71-80$ & 7 & 41,18 & $71-80$ & 1 & 5,88 \\
\hline $81-90$ & 1 & 5,88 & $81-90$ & 4 & 23,53 \\
\hline $91-100$ & 0 & 0,00 & $91-100$ & 12 & 70,59 \\
\hline Total & $\mathbf{1 7}$ & $\mathbf{1 0 0}$ & Total & $\mathbf{1 7}$ & $\mathbf{1 0 0}$ \\
\hline Mean & $\mathbf{6 7 , 2 3}$ & & Mean & $\mathbf{9 0 , 3 4}$ & \\
\hline Stdev & $\mathbf{1 0 , 7 3}$ & & Stdev & $\mathbf{4 , 3 3}$ & \\
\hline
\end{tabular}

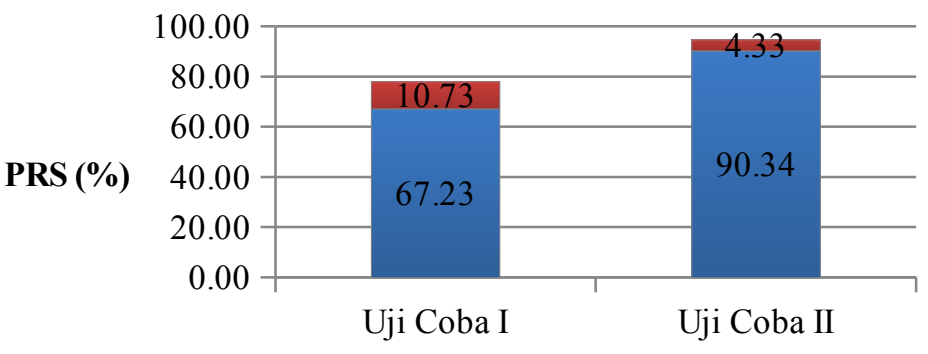

Observation of Student Reading Interest

Figure 4. Pictures of Student Reading Interest Based on Observations

The table and figure above show that grade $\mathrm{V}$ students obtained observation values for the average reading interest of PPKn, namely 67.23 in the first trial and 90.34 in the second trial. This shows that there is a difference even an increase in the score of PPKn reading interest observation from the first product trial to the second product trial.

\section{3) The Results of Product Effectiveness Test}

Gain score or increase in interest in reading PPKn for grade V students was obtained from value reduction in trial II and trial I. The results of the gain score test for students who used Comic Teaching Materials based on Questionnaire and based on Observations are presented in the table and figure below.

Table 8. Gain Score Test Results

\begin{tabular}{cccccc}
\hline & \multicolumn{1}{c}{ Increased Questionnaire } & \multicolumn{3}{c}{ Increased Observation } \\
\hline Score & F & f relative (\%) & Score & F & f relative (\%) \\
\hline $1-10$ & 1 & 5.88 & $1-10$ & 1 & 5.88 \\
\hline $11-20$ & 4 & 23,53 & $11-20$ & 5 & 29.41 \\
\hline $21-30$ & 12 & 70,59 & $21-30$ & 7 & 41.18 \\
\hline $31-40$ & 0 & 0.00 & $31-40$ & 4 & 23.53 \\
\hline Total & $\mathbf{1 7}$ & $\mathbf{1 0 0}$ & Total & $\mathbf{1 7}$ & $\mathbf{1 0 0}$ \\
\hline Mean & $\mathbf{2 3 , 2 4}$ & $\mathbf{5}$ & Mean & $\mathbf{2 3 . 1 1}$ \\
\hline Stdev & $\mathbf{5 , 5 7}$ & Stdev & $\mathbf{9 . 2 9}$ \\
\hline
\end{tabular}




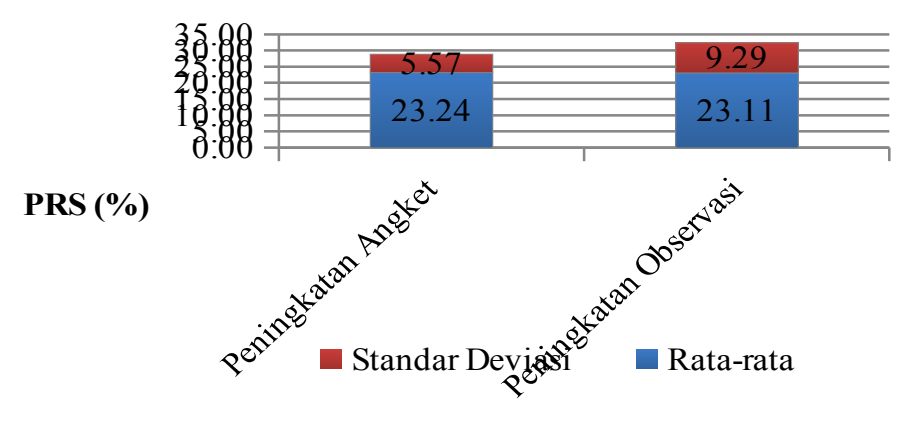

Figure 5. Picture of Gain Score Test Results

\section{Conclusion}

This stage (evaluation) is the final stage in this study. Evaluation is carried out on the results of product feasibility tests and product effectiveness testing in increasing PPKn reading interest. The evaluation results are used as the final conclusions regarding the results of product analysis developed, and used as a benchmark for the success of researchers in answering questions in this study. Therefore the average rating of the expert validator, which is equal to $95.56 \%$ or categorized as very valid so it is stated that the developed Comic teaching material is very suitable for use by fifth grade students of elementary schools, especially to increase their reading interest in PPKn subjects. 
Then the average increase in students 'reading interest in PPKn using comic teaching materials either through questionnaires or observations has reached a high improvement category with a score of more than 23. So it is concluded that Comic teaching materials developed effectively can increase students' reading interest, especially in the eyes PPKn lessons with joint decision material for fifth grade elementary school students.

\section{References}

Budiningsih, Asri. Belajar dan Pembelajaran, Jakarta: Rineka Cipta, 2012.

Diana \& Bagus, "Pengembangan Bahan Ajar Komik Berbasis Pendidikan Karakter untuk Meningkatkan Kemampuan Pemecahan Masalah pada Materi Segiempat", Jurnal Pendidikan Matematika,2

(2), 2016, hal. $1-8$, https://ejournal.stkipmpringsewulpg.ac.id/index.php/edumath/article/view/176 diakses 12 April 2018. 
Danaswari, Resti Wahyu., dkk. "Pengembangan Bahan Ajar dalam Bentuk Media Komik untuk Meningkatkan Hasil Belajar Siswa Kelas X SMAN 9 Cirebon pada Pokok Bahasan Ekosistem", Jurnal Scientiae Educatia, 2 (2), November 2013, hal.1-17, http://www.syekhnurjati.ac.id/jurnal/index.php/sceducatia/article/view/477/453 diakses 17 April 2018.

Darmadi, Hamid, Dimensi-Dimensi Metode Penelitian Pendidikan dan Sosial, Bandung: Alfabeta, 2013.

Fahyuni, E F \& Imam Fauji. "Pengembangan Komik Akidah Akhlak untuk Meningkatkan Minat Baca dan Prestasi Belajar Siswa Sekolah Dasar", Halaqa: Islamic Education Journal, 1 (1), Juni 2017, hal. 17-26. http://ojs.umsida.ac.id/index.php/halaqa diakses 18 Desember 2017.

Gagne, dkk.Principles of Instructional Design ( $5^{\text {th }}$ ed.), Belmont, CA: Thomson/ Wadsworth, 2005.

Ifdhal, dkk.,"Pengembangan Bahan Ajar Berbentuk Komik pada Mata Pelajaran Ilmu Bangunan Gedung (IBG) Kelas X SMK Negeri 5 Padang”, Journal of Civil Engineering and Vocational Education,1 (3), 2003, hal. 211-220, http://ejournal.unp.ac.id/index.php/cived/article/view/2507 diakses 12 April 2018.

Januszewski, A., Molenda, M Educational Technology, New York: Lawrence Erlbaum Associates, 2008.

Kusrianto, Adi. Pengantar Desain Komunikasi Visual, Yogyakarta: Andi Offset, 2007.

Khairi, Ashabul., "Pengembangan Media Komik Berbasis Karakter Untuk Siswa Sekolah Dasar", Jurnal PPKn \& Hukum,11 (1), 2016, hal. 98-110. https://ejournal.unri.ac.id/index.php/JPB/article/download/3658/3564 diakses 22 Desember 2017.

Lickona. Education for Character: Mendidik untuk Membentuk Karakter. Jakarta: Bumi Aksara, 2012.

Lubis, Maulana Arafat. "The Using of Comic as a Teaching Material in Building Character of Elementary School Students". JMIE: Journal of Madrasah Ibtidaiyah Education, 12 (2), 2017, hal. 246-258. http://ejournal.adpgmiindonesia.com/index.php/jmie/article/view/44diaksespadatanggal 27 April 2018.

Lubis, Maulana Arafat., "Pengembangan Bahan Ajar Komik Berbasis Model Problem Based Learning”, Jurnal Tematik, 6 (3), hal. 199-203, Medan: Prodi Pendidikan Dasar Pascasarjana UNIMED, 2016.

Lubis, Maulana Arafat. Pengembangan Profesionalisme Guru Madrasah Ibtidaiyah Pada Abad 21 dalam Membuat Bahan Ajar Leaflet, 10 April 2018, hal. 1-22. http://doi.org/10.17605/OSF.IO/VSEZK diakses 5 Mei 2018.

Lubis, Maulana Arafat.,Mutia S., Isma Y. Kualitas Bahan Ajar Komik dalam Tingkat Pemahaman Belajar Peserta Didik". Prosiding Seminar Nasional Tahunan Fakultas Ilmu Sosial Universitas Negeri Medan Tahun 2017, 2017, hal. 45-50. http://semnasfis.unimed.ac.id diakses pada tanggal 12 April 2018.

Lubis, Maulana Arafat. (2016). Pengembangan Bahan Ajar Komik Berbasis Model Problem Based Learning untuk Meningkatkan Hasil Belajar PKn Siswa Kelas V MIN Medan Sunggal. Tesis. Medan: Program Pascasarjana Universitas Negeri Medan. http://digilib.unimed.ac.id/id/eprint/8270 diakses 18 Mei 2018. 
Mediagus, Perangkat Pembelajaran Komik, Padang: Jurusan Seni Rupa Fakultas Bahasa dan Seni UNP, 2012.

Mei Fita Asri Untari \& Aprilianta Adi Saputra, "Kefektifan Media Komik Terhadap Kemampuan Membaca Pemahaman Pada Siswa Kelas IV SD", Jurnal Mimbar Sekolah Dasar, 3 (1), 2016, hal. 26-36, http://download.portalgaruda.org/article.php?

article $=448345 \& \mathrm{val}=7996 \&$ title $=$ KEEFEKTIFAN\%20MEDIA $\% 20 \mathrm{KOMIK}$ \%20TERHADAP\%20KEMAMPUAN\%20MEMBACA\%20PEMAHAMAN \%20PADA\%20SISWA\%20KELAS\%20IV\%20SD diakses 22 Desember 2017.

Permendikbud No. 58 Tahun 2013 Tentang Kurikulum 2013.

Sugiyono, Metode Penelitian Kuantitatif, Kualitatif, dan R\&D, Bandung: Alfabeta, 2016.

Setyosari, Punaji, Metode Penelitian Pendidikan dan Pengembangan, Edisi Ketiga Jakarta: Kencana, 2013.

Scott, McCloud. Understanding Comics, E-book, 2012.

Somadayo, Samsu., Strategi dan Teknik Pembelajaran Membaca: Edisi Pertama. Yogyakarta: Graha Ilmu, 2011.

Sudjana, Media Pengajaran, Bandung: Sinar Baru Algasindo, 2007.

Triatma,Ilham Nur., dkk. "Minat Baca Pada Siswa Kelas Vi Sekolah Dasar Negeri Delegan 2 Prambanan Sleman Yogyakarta", E-Jurnal Prodi Teknologi Pendidikan, Vol. 5 Nomor 6 , 2016,hal.

$166-$ 178,http://journal.student.uny.ac.id/ojs/index.php/fiptp/article/view/3098/2794dia kses 17 April 2018.

Wahab, Abdul., dkk. "Pengembangan Bahan Ajar Komik Pada Materi Sistem Transportasi Makhluk Hidup Untuk Menumbuhkan Minat Baca dan Meningkatkan Hasil Belajar". Jurnal Pendidikan Sains Pascasarjana Universitas Negeri Surabaya, 6 (1), 2016, hal. 1090-1099. (https://journal.unesa.ac.id/index.php/jpps/article/download/524/377) diakses 12 April 2018. 